\title{
Why deep drilling in the Colônia Basin (Brazil)?
}

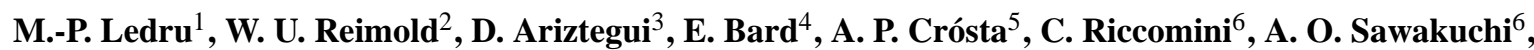 \\ and workshop participants \\ ${ }^{1}$ ISEM, Montpellier University, CNRS, IRD, EPHE, France \\ ${ }^{2}$ Museum für Naturkunde - Leibniz Institute for Evolution and Biodiversity Science, Unter den Linden 6, \\ 10099 Berlin, and Humboldt Universität zu Berlin, Germany \\ ${ }^{3}$ Department of Earth Sciences, University of Geneva, Switzerland \\ ${ }^{4}$ CEREGE Aix-Marseille University, CNRS, IRD, College de France, France \\ ${ }^{5}$ Institute of Geosciences, University of Campinas, Campinas, SP, Brazil \\ ${ }^{6}$ Institute of Geosciences, University of São Paulo, São Paulo, SP, Brazil
}

Correspondence to: M.-P. Ledru (marie-pierre.ledru@ird.fr)

Received: 17 February 2015 - Revised: 7 May 2015 - Accepted: 11 May 2015 - Published: 17 December 2015

\begin{abstract}
The Colônia Deep Drilling Project held its first International Continental Scientific Drilling Program (ICDP) workshop in September 2014 at the University of São Paulo (Brazil). Twenty-seven experts from six countries discussed the feasibility and the expectations of a deep drilling in the structure of Colônia located at the southwestern margin of the city of São Paulo. After presenting the studies performed at the site during the last decades, participants focused on the objectives, priorities and detailed planning for a full deep-drilling proposal. An excursion to the site and new auger coring showed the importance of the Colônia site for studying the evolution of a tropical rainforest and to evaluate the interplay between the South American summer monsoon, the Intertropical Convergence Zone (ITCZ) and the southern Westerlies belt during the last 5 million years. In addition, deep drilling will eventually solve the still unresolved issue of the origin of the structure of Colônia as a result of meteorite impact or endogenous processes.
\end{abstract}

1

In September 2014, an International Continental Scientific Drilling Program (ICDP) sponsored workshop was organized in São Paulo (Brazil), gathering a large group of scientists involved in the study of various aspects of the Colônia structure. This circular structure of $3.6 \mathrm{~km}$ diameter is located in the coastal mountain range of Brazil, in the Atlantic Forest domain, at the periphery of the city of São Paulo $\left(23^{\circ} 52^{\prime \prime} \mathrm{S}\right.$ $46^{\circ} 42^{\prime} 20^{\prime \prime}$ W, $900 \mathrm{~m}$ a.s.l.; Fig. 1). The structure has been known, and its origin debated, since the early 1960s. The first geophysical investigations suggested that the basin could be as deep as 300 to $450 \mathrm{~m}$, and results of several complementary geophysical methods have since been used to constrain the geometry of the crater-like structure and to provide a preliminary stratigraphic framework. The structure was formed in crystalline basement rocks, mostly granitic gneiss, some schists and quartzites of Neoproterozoic age (600-700 Ma;
Hasui et al., 1975). Their presence provides the only available (maximum) age constraint for the formation of this structure. The near-circular rim is formed by a prominent annular ring of hills rising up to $125 \mathrm{~m}$ above the inner depression of Precambrian basement rocks. The basin stratigraphy essentially comprises organic-rich and fine-grained sediments (silt and clay), with intercalations of sandy mud. The presence of Precambrian rock fragments in a matrixsupported conglomerate found at $\sim 350 \mathrm{~m}$ depth points towards a fanglomeratic deposit derived from the highest parts of the outer rim and is most probably related to the initial infilling of the depression (Riccomini et al., 2011).

Riccomini et al. (2011) discussed various alternative processes to explain the origin of the Colônia structure. Impact cratering has remained the preferred agent (e.g., Velazquez et al., 2014) despite a lack of unambiguous evidence. This impact hypothesis is supported by the overall geometry of the structure because the geology does not provide any other 
(a)
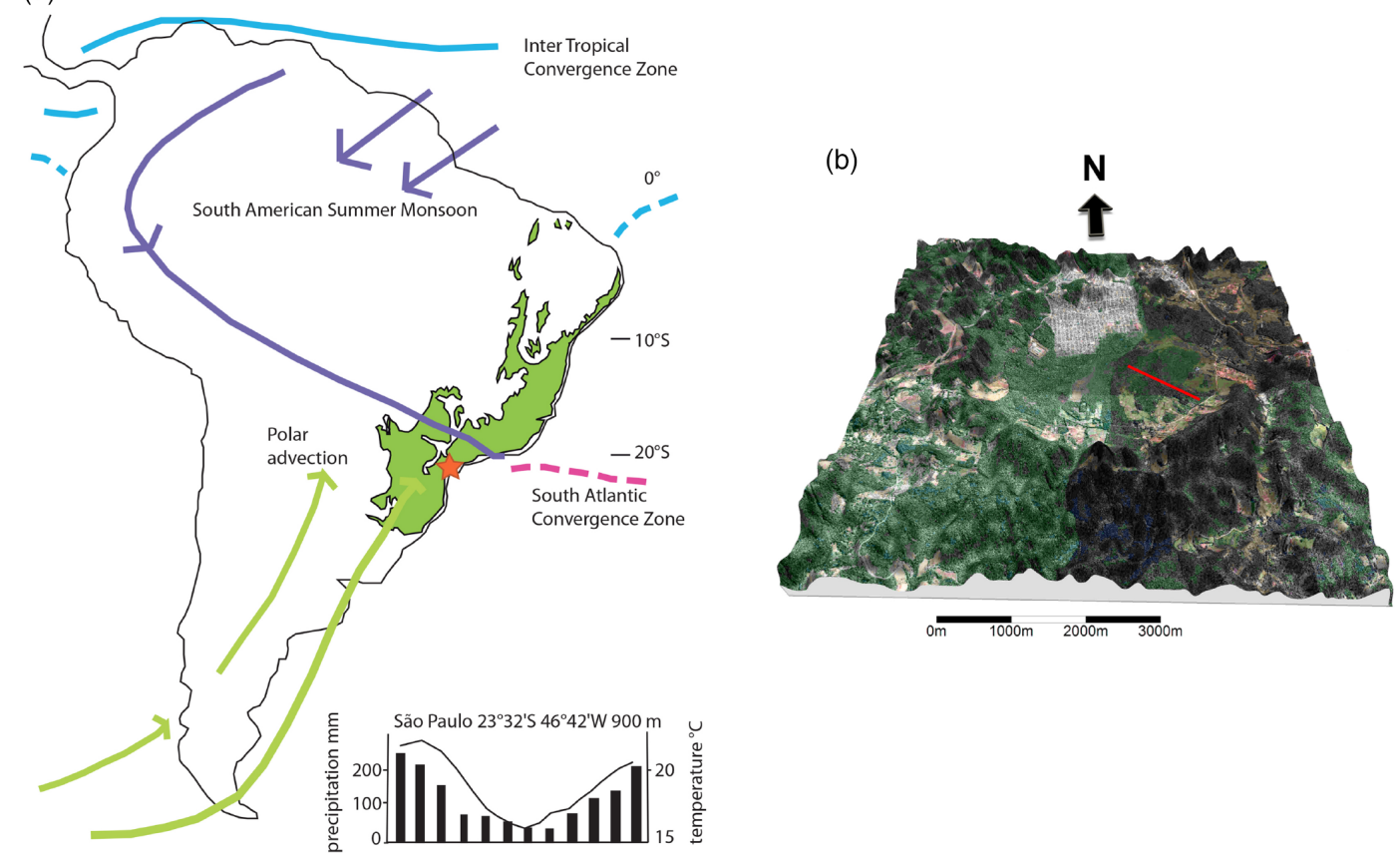

Figure 1. (a) Map of South America. The green area illustrates the present extent of the Atlantic rainforest and the red star indicates the location of Colônia. The site is located in a key position between the austral summer (north of Colônia) and winter (south of Colônia) rainfall pattern and atmospheric circulation. The northern circulation is dominant today with the activity of the South American summer monsoon (purple) and Intertropical Convergence Zone (ITCZ) seasonal shifts (light blue plain and dotted lines showing austral winter and summer positions, respectively). (b) 3-D view of the Colônia structure combining an Ikonos satellite image and a digital elevation model with a $6.5 x$ vertical exaggeration. The red line indicates the present extent of the bog.

plausible explanation for the formation of such a distinct circular shape by endogenic or exogenic processes. Riccomini et al. (2011) also noted that the current depth-to-diameter ratio is different from similarly sized and comparatively deeper known impact structures (e.g., Brent Crater, Ontario, attains a depth in the inner part of the basin of $1000 \mathrm{~m}$ ). This was interpreted as indicating that the crater could have been substantially eroded since its formation. No datable material related to basin formation has been found at Colônia so far. Consequently, comprehensive drilling of the structure is required to provide a means of constraining its origin and to have a chance of obtaining datable material (Reimold et al., 2014).

The Colônia Basin is a unique site for regional as well as global paleoclimatic investigations (Fig. 1a), as it has remained a closed basin system ever since its formation. Based on geophysical data by Riccomini et al. (2011), the continuous sedimentary infill could provide an extended and unique paleoenvironmental record for the Southern Hemisphere tropics and, in particular, for Atlantic tropical rainforest evolution. Much of what is currently known about the Colônia infill comes from sedimentological and palynological studies of the upper $8 \mathrm{~m}$, which provided a record of 130 ka (Fig. 2; Riccomini et al., 1991; Ledru et al., 2005,
2009). In 2009, Ledru et al. estimated that the complete depositional record could span at least 1.5 to $2.5 \mathrm{Ma}$.

\section{Scientific issues}

The Colônia Basin is located on the southernmost influence of the South American subtropical monsoon (SASM) and the northernmost limit of polar air advections (Fig. 1a). Previous paleoclimatic studies have shown that these climatic limits have shifted during the last $130 \mathrm{ka}$. For instance, speleothem records from relatively close to the Colônia site show that orbital cycles, and more particularly the precession signal, control the distribution of regional precipitation (Cruz et al., 2005). Pollen analysis reveals that this precession signal has also paced phases of expansion and regression of the Atlantic rainforest (Ledru et al., 2009; Fig. 2). Consequently, Colônia offers an ideal site to test hypotheses of paleoecological responses to climate change; the impact of orbital cycles on tropical moisture regimes and water resources; the speciation of living organisms ranging from plants to ostracods; biodiversity processes; links of this area with the Amazon rainforest during several glacial-interglacial cycles; and to provide information on the Tertiary-Quaternary boundary in the Southern Hemisphere. Thus, drilling Colônia will allow us to test hypotheses relating to vegetation community compo- 

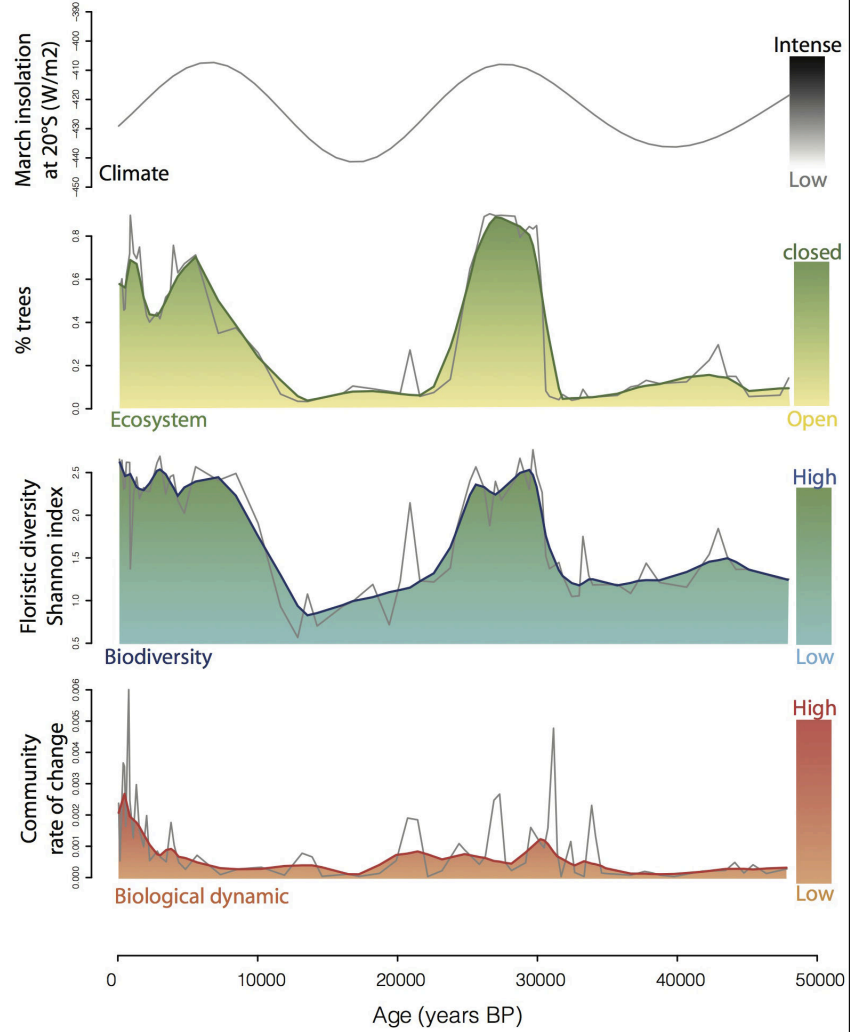

Figure 2. Synthetic diagram showing, from top to bottom, the insolation at $20^{\circ} \mathrm{S}$ (from Berger and Loutre, 1991), the arboreal pollen (AP) frequencies, the floristic diversity index, and the community rate of change in the pollen record of Colônia during the last $50 \mathrm{ka}$. The figure illustrates the relation between the forest expansion/regression phases and the pace of the precession signal (modified by L. Bremond and C. Favier in Prospectives Ecologie Tropicale 2014).

sition, ecosystem resilience, niche effectivity, and migratory response. Additionally, for the first time, the limits of deep microbial life can be investigated in a deep drilling project at this southern latitude.

Several open questions regarding the Colônia structure can be answered only through deep drilling.

1. What is the origin of this enigmatic basin structure?

Rock samples retrieved from the drilling will be investigated for the occurrence of unambiguous shock (impact) metamorphic features, such as shatter cones and planar deformation features. Any possibly observed shatter cones will be investigated visually. Other microscopic shock features (e.g., planar deformation features - PDF) will be investigated by optical microscopy and, if required, by electron microscopic techniques. Should the structure be of impact origin, shock deformed minerals may occur in impact breccias, possibly even including impact melt rock. The latter would provide the best means for dating of the basin-forming event.
Should impact melt rock be drilled, it may also contain a trace of the extraterrestrial projectile that might be amenable for identification of the projectile type. Pseudotachylitic breccia in the sub-basin basement could also be related to the basin-forming event and may be datable. Hydrothermal activity might have affected a crater-floor section and could become an important subject of chemical and petrographic investigation.

2. What is the age of the structure?

Drilling deep will allow searching for melt fragments where an absolute date may be established by radiometric dating using the ${ }^{40} \mathrm{Ar} /{ }^{39} \mathrm{Ar}$ method. Paleomagnetism will be performed continuously on the core to establish the magnetic stratigraphy, and combined optically stimulated luminescence (OSL) and radiocarbon datings will constrain the age model on the last four glacial/interglacial cycles. Additionally, statistical analyses will be used to compare changes in geo- and bio-indicators with neighboring speleothem and marine records as well as to identify hiatuses within the sediment deposit.

3. How did the tropical Atlantic rainforest respond to several successive glacial-interglacial and orbital cycles?

While the last glacial maximum is the expression of the eccentricity element of the orbital cycle, paleoclimatic reconstructions from speleothems (116 ka) suggest that the precessional element of the orbital cycle was rather the main driver for changes in precipitation regimes in eastern South America (Cruz et al., 2005). However, spectral analysis on arboreal pollen frequencies on three long Quaternary records of vegetation in the tropics (Fuquene, $1 \mathrm{Ma}$, Bogota et al., 2011; Lynch Crater, $230 \mathrm{ka}$, Kershaw et al., 2007; Colônia, $130 \mathrm{ka}$, Ledru et al., 2009) revealed the imprint of the three orbital cycles, eccentricity, obliquity and precession, in the past distribution and composition of the rainforest. This new field of research still needs more long record studies.

4. What are the evolutional processes of tropical species?

While most Amazon and Atlantic forest species started to diverge during the Tertiary, a large number of new species emerged during the Quaternary. Recently, phylogeographers working in the Atlantic rainforest showed that diversification and molecular timescales are not always correlated with successive glacial maxima (Ribas et al., 2012). Long records will contribute to characterizing the nature of the link between divergence and changes in the Earth's total thermal energy.

5. How did changes in the equator-pole temperature gradient impact on the distribution of the Atlantic rainforest? 
The long pollen records of Fuquene in Colombia (Bogota et al., 2011) and Lynch Crater in Australia (Kershaw et al., 2007) show that the variability of the temperature gradient between low and high latitudes defines the strength and position of the South American summer monsoon on the continent and is paced by the obliquity signal at $\sim 40 \mathrm{ka}$. The high-resolution record of Potrok Aike, obtained from a previous ICDP-sponsored lake drilling project (Zolitschka et al., 2013), will be used to define the shifts of the wind belts and their impact on the SASM amplitude and intensity at the latitude of Colônia during the late glacial as well as to characterize the link between low- and high-latitude circulation.

6. What is the link to Amazon rainforest and to Andean forest?

A possible link between the Amazon and Atlantic forests was observed in northeastern Brazil during the late glacial and between the Andean and Atlantic forests in southeastern Brazil during the last glacial (Ledru et al., 2009). How often were these links repeated during the Cenozoic?

7. What is the nature and extension of the subsurface microbial biosphere in this environment?

Peat bogs are significant contributors to the global carbon cycle, acting as large repositories of atmospheric carbon and containing over one-third of the organic carbon in global soils. Emissions of methane and $\mathrm{CO}_{2}$ greenhouse gases occur primarily by two processes: methanogenesis and methane oxidation that are closely associated with microbial activity (Ariztegui et al., 2015). Determining their activity in both the peat bog and the older lacustrine sediments will provide unique information about microbial activity in contrasting environmental conditions (glacial-interglacial) and their record in the sediments.

\section{Outcomes of the São Paulo workshop on Colônia deep drilling}

Twenty-seven scientists from six countries (Australia, Brazil, France, Germany, Switzerland, and the USA) participated in a workshop in São Paulo, Brazil, from 26 to 29 September 2014 , to discuss scientific priorities and logistical requirements for accomplishing a deep drilling project at Colônia. The workshop was held at the Geosciences Institute of the University of São Paulo (USP). This location allowed students and faculty of the USP to actively participate in the workshop and closely interact with the science team.

Several invited speakers introduced the aspects that constitute the backbone of the Colônia project, including presentations on
1. a comparison of the Colônia structure with similarly sized impact structures in South America and elsewhere;

2. relevant Quaternary geological and paleoecological research;

3. review of the late Quaternary climatic controls based on stable isotope records;

4. the paleoecological potential of Colônia sediments and plausible links to planned projects on tropical biodiversity processes in the Atlantic rainforest;

5. methods and problems related to age modeling of Quaternary sediments;

6. investigating the subsurface biosphere in peat bog and lacustrine sediments; and

7. technical issues of deep drilling.

Additionally, several speakers presented results of previous drilling projects with emphasis on ICDP procedures and projects (F. Anselmetti, Switzerland; U. Harms, Germany; J. Overpeck, USA).

One full day was spent visiting the Colônia site located in the municipality of São Paulo some $42 \mathrm{~km}$ south of the city center. The group could familiarize itself with the logistical facilities offered by the relative proximity to the city, with accessible roads right into the basin and a track leading towards the center of the shallow bog. Using a Russian corer, a $14 \mathrm{~m}$ long sediment record was retrieved from the bog during this excursion (Fig. 3). This new core will provide datable material to clarify existing issues concerning the currently available age model. Furthermore, this core has shown the presence of laminated lake sediments below the topmost peat (Fig. 4).

A number of new aspects arose during the workshop, including the following.

- Results of reconnaissance seismic-reflection surveys suggest that the basin of the Colônia structure contains a thicker sedimentary sequence than previously thought. Further seismic investigations are needed to cover the entire structure, including the previously non-analyzed centralmost section, and to better constrain the best drilling location (Fig. 5).

- Sediment cores collected in 1989 were 7 and 8 m long, showing the presence of a thick and compacted peat (Riccomini et al., 2005). However, the lacustrine deposits in the new $14 \mathrm{~m}$ long core retrieved during the workshop open up new research perspectives.

- Preliminary luminescence data obtained at the Luminescence and Gamma Spectrometry Laboratory of the University of Sao Paulo (LEGAL-USP) during the 


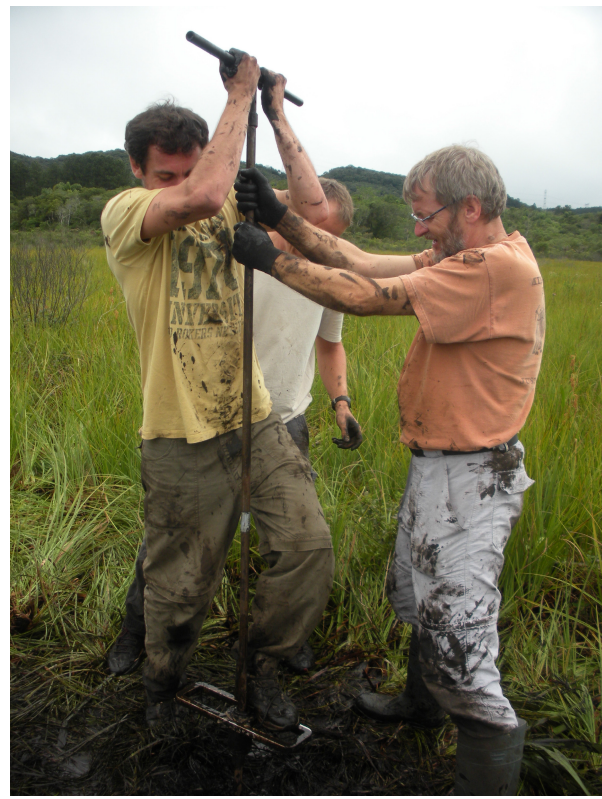

Figure 3. The drilling of core CO 14-1 performed during the excursion to the structure of Colônia. Photo credit: Marie-Pierre Ledru.

night after coring showed quartz and potassium-feldspar grains suitable for optically stimulated luminescence (OSL) dating. Aliquots of potassium-feldspar grains indicated good infrared (IR) stimulated luminescence and post-IR signals able to recover a radiation equivalent dose up to at least $600 \mathrm{~Gy}$. Aliquots of quartz grains presented high blue-stimulated luminescence and isothermal thermoluminescence (ITL) signals suitable for measurement of doses up to 150 and $500 \mathrm{~Gy}$, respectively. The luminescence signals tested would be suitable for dating of sediments back to at least $400 \mathrm{ka}$, considering radiation dose rates of 1.2 and $1.7 \mathrm{~Gy} \mathrm{ka}^{-1}$, respectively measured for quartz and potassium feldspar. Other luminescence signals such as thermal transfer OSL and violet stimulated luminescence (VSL) can be tested as alternatives to extend the age range, possibly beyond the Quaternary.

- Paleomagnetic tests performed on a short core collected in 2010 had already provided the presence of a good magnetic signal, which will make magnetostratigraphy an additional dating tool for the part of the record older than the Brunhes-Matuyama boundary $(0.78 \mathrm{Ma})$.

- Qualitative and semi-quantitative determinations of the mineral assemblage will complete the lithological description of the Colônia sedimentary sequence. The crystallinity index is expected to increase in the lacustrine sediment succession, with respect to mineralogy in the present bog. Detrital mineral input allows inferring of the degree of weathering at the time of deposition, whereas authigenic minerals are controlled by the bio-

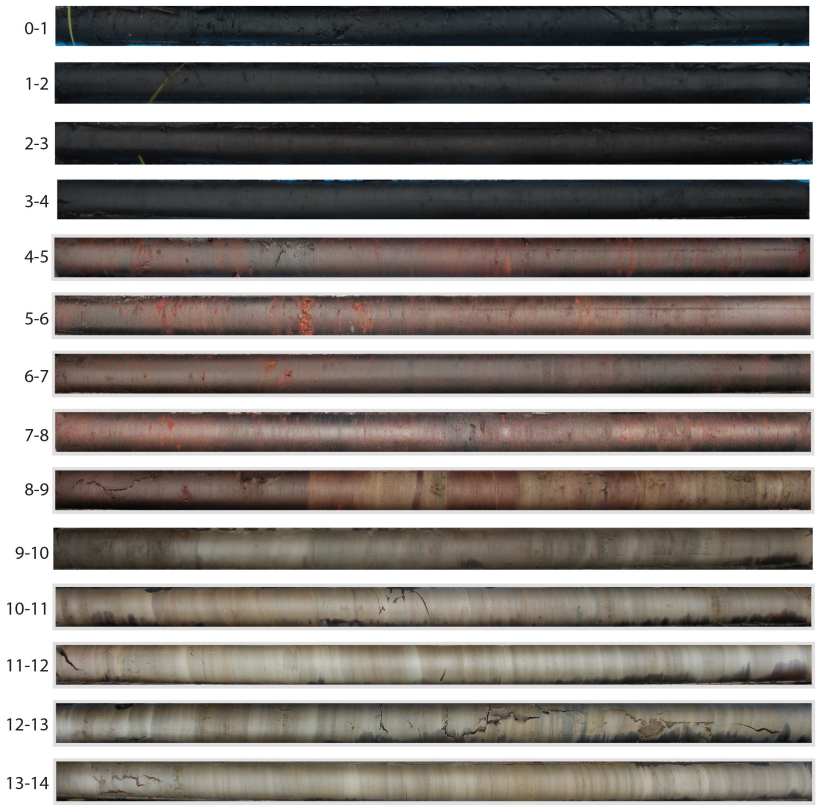

Figure 4. Sediments of the 14 sections of core CO 14-1 showing grey lacustrine deposits below $9 \mathrm{~m}$ depth, a transition between peat and lacustrine deposits between 9 and $8 \mathrm{~m}$, and peat in the upper section.

geochemical cyclicity within the paleo-lake. Additionally, detailed mineralogical investigations might provide information on whether cryptotephras are preserved in the Colônia sequence and can be used as another dating tool.

- Stable isotopes on organic matter (nitrogen and organic carbon isotope composition) and on bulk carbonates (carbon and oxygen isotopes) will be used as potential proxies for nutrient cycling, carbon sources, and climatic change.

- The lacustrine sections will be investigated for biological remains such as diatoms and ostracods allowing a quantitative estimation of lake level changes and associated variations in water chemistry.

\section{Opportunities and tasks}

The workshop participants concluded that additional pilot data must be acquired before presenting a full proposal in January 2016. In the course of the coming months, the newly retrieved core will be extensively analyzed, including nondestructive X-ray diffraction (XRD) analysis of bulk powder samples; stable isotope analysis; paleomagnetism; OSL and radiocarbon dating; and ostracod and diatom analysis. An improvement of the presently available geophysical data is critical. New gravimetric data have already been ac- 
(a)

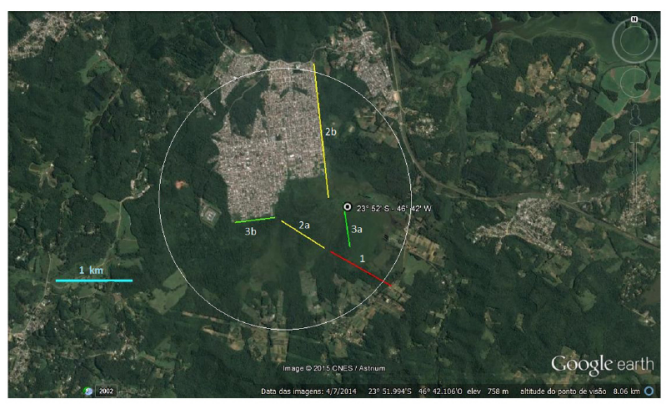

(b)

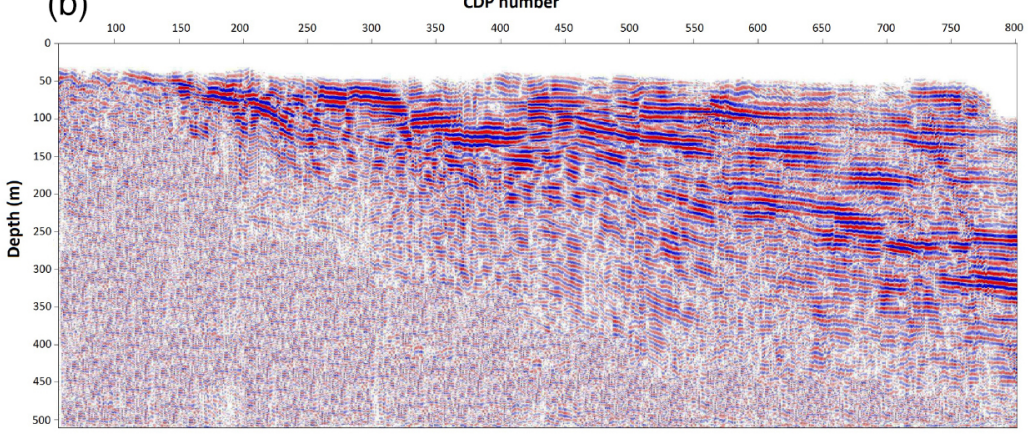

Figure 5. (a) Satellite view of the structure of Colônia showing the location of the 2010 seismic section (red line) and the sections planned for 2015. (b) Results of the 2010 seismic section along the Colônia structure (common depth point (CDP) trace interval $=1 \mathrm{~m}$ ). The bright red and blue colours show the uninterpreted sedimentary infill of the basin(from Riccomini et al., 2011).

quired and an additional seismic data acquisition campaign is planned for the dry season of 2015 (May-July; Fig. 5a).

A second workshop of PIs and scientific team members was called for February 2015 at the University of Campinas, in the city of Campinas (Brazil). The main objective for this meeting was the discussion of progress and organization to acquire additional seismic profiles covering the central part of the structure, as well as debate of the preliminary results of the new core. Presentations by and about tender drilling companies allowed assessing of the budget requirements for drilling operations to be comprehensive but economic.

\section{Participants in the workshop}

Flavio Anselmetti, Daniel Ariztegui, Laurent Augustin, Laurent Bremond, Manoel Cardoso, Ana Carolina Carnaval, Marlei Chamani, Cristiano Chiessi, Alvaro Crósta, Francisco Cruz, Paulo De Oliveira, Thomas Fairchild, Charly Favier, José Antonio Ferrari, Maria Judite Garcia, Uli Harms, Fred Jourdan, Marie-Pierre Ledru, Vanda Medeiros, Cristina Miyaki, Grace Oliveira, Jonathan Overpeck, Vania Pivello, Renato Prado, Fabiano Pupim, Fresia Ricardi-Branco, Rudney de Almeida Santos, Wolf Uwe Reimold, Claudio Riccomini, Patricia Roeser, Lucy Sant'Anna, André Sawakuchi, Giancarlo Scardia, Tim Shanahan, Nicolás Strikis, Ricardo Trindade, Marcos Vasconcelos, Ilana Wainer, Suely Yoshinaga Pereira, and numerous other colleagues and students that listened to the presentations.

Acknowledgements. We thank ICDP for financial support of the workshop and the 27 participants in the Colônia Deep Drilling workshop for their contributions and enthusiastic support of the planned drilling in the Colônia Basin. We are most grateful to U. Harms of the ICDP central office in Potsdam for his technical advice and encouragement to further develop this project. We thank L. Augustin and the Centre de Carottage et de Forage National (C2FN) at the Institut National des Sciences de l'Univers (INSU), France, L. Bremond and C. Favier for the coring during the workshop, and P. R. dos Santos (Vice Director of the Institute of Geosciences of the University of São Paulo, USP) for his warm welcome, and the professors and students at USP that provided a great meeting venue. This research is partially co-funded by FAPESP (BIOTA, 2013/50297-0), NSF (DEB 1343578) and NASA, through the Dimensions of Biodiversity Program.

Edited by: G. Camoin

Reviewed by: D. Hodell and B. Zolitschka

\section{References}

Ariztegui, D., Thomas, C., and Vuillemin, A.: Present and future of subsurface biosphere studies in lacustrine sediments through scientific drilling, Internat. J. Earth Sci., doi:10.1007/s00531-0151148-4, 2015.

Berger, A. and Loutre, M. F.: Insolation values for the climate of the last 10 million of years, Quaternary Sci. Rev., 10, 297-317, 1991.

Bogotá, R. G., Groot, M. H. M., Hooghiemstra, H., Lourens, L. J., Van Der Linden, M., and Berrio, J. C.: Rapid climate change from north andean Lake Fúquene pollen records driven by obliquity: Implications for a basin-wide biostratigraphic zonation for the last 284 ka, Quaternary Sci. Rev., 30, 3321-3337, 2011.

Cruz, F. W., Burns, S. J., Karmann, I., Sharp, W. D., Vuille, M., Cardoso, A. O., Ferrari, J. A., Silva Dias, P. L., and Viana, O. J.: Insolation-driven changes in atmospheric circulation over the past 116000 years in subtropical Brazil, Nature, 434, 63-66, 2005.

Hasui Y., Carneiro, C. D. R., and Coimbra, A. M.: The Ribeira folded belt, Revista Brasileira de Geociências, 5, 257-266, 1975.

Kershaw, A. P., Bretherton, S. C., and Van Der Kaars, S.: A complete pollen record of the last $230 \mathrm{ka}$ from Lynch's crater, northeastern Australia, Palaeogeogr. Palaeoecol., 251, 23-45, 2007.

Ledru, M.-P., Rousseau, D.-D., Cruz, F. W. J., Karmann, I., Riccomini, C., and Martin, L.: Paleoclimate changes during the last $100 \mathrm{ka}$ from a record in the Brazilian Atlantic rainforest region and interhemispheric comparison, Quaternary Res., 64, 444-450, 2005.

Ledru, M.-P., Mourguiart, P., and Riccomini, C.: Related changes in biodiversity, insolation and climate in the Atlantic rainforest 
since the last interglacial, Palaeogeogr. Palaeoecol., 271, 140152, 2009.

Prospective Ecologie Tropicale: INEE CNRS, 6, 3, 2014.

Reimold, W. U., Ferrière, L., Deutsch, A., and Koeberl, C.: Impact controversies: Impact recognition criteria and related issues, Meteorit. Planet. Sci., 49, 723-731, 2014.

Ribas, C. C., Aleixo, A., Nogueira, A. C. R., Miyaki, C. Y., and Cracraft, J.: A palaeobiogeographic model for biotic diversification within Amazonia over the past three million years, P. Roy Soc. B-Biol. Sci., 279, 681-689, 2012.

Riccomini, C., Turcq, B., Martin, L., Moreira, M. Z., and Lorscheitter, M. L.: The Colônia astrobleme, Brasil, Revista do Instituto Geológico, 12, 87-94, 1991.

Riccomini C., Turcq, B., Ledru, M.-P., Sant'Anna, L. G., and Ferrari, J. A.: Cratera de Colônia, SP - Provável astroblema com registros do paleoclima quaternário na Grande São Paulo, in: Sítios Geológicos e Paleontológicos do Brasil, edited by: Winge, M., Schobbenhaus, C., Berbert-Born, M., Queiroz, E. T., Campos, D. A., and Souza, C. R. G., http://sigep.cprm.gov.br/ sitio116/sitio116.pdf (last access: 28 May 2015), 2005.
Riccomini, C., Crósta, A. P., Prado, R. L., Ledru, M.-P., Turcq, B. J., Sant'Anna, L. G., Ferrari, J. A., and Reimold, W. U.: The Colônia Structure, São Paulo, Brazil, Meteorit. Planet. Sci., 46, 1630-1639, 2011.

Velázquez, V. F., Colonna, J., Martins Sallun, A. E., Azevedo Sobrinho, J. M., Sallun Filho, W., and Paiva Jr, P. C. A.: The Colônia Impact Crater: Geological Heritage and Natural Patrimony in the Southern Metropolitan Region of São Paulo, Brazil, Geoheritage, 6, 283-290, 2014.

Zolitschka, B., Anselmetti, F., Ariztegui, D., Corbella, H., Francus, P., Lücke, A., Maidana, N. I., Ohlendorf, C., Schäbitz, F., and Wastegård, S.: Environment and climate of the last 51000 years new insights from the Potrok Aike maar lake Sediment Archive Drilling prOject (PASADO), Quaternary Sci. Rev., 71, 1-12, 2013. 